\title{
THE CRUSTACEAN AND MOLLUSCAN FAUNA OF TASMANIAN SALTMARSHES
}

\author{
Alastair M.M. Richardson, Roy Swain and Vera Wong
}

(with four tables and six text-figures)

\begin{abstract}
Richaroson, A.M.M., Swain, R. \& Wong, V., 1997 (31:viii): The crustacean and molluscan fauna of Tasmanian saltmarshes. Pap. Proc. R. Soc. Tasm. 131: 21-30. https://doi.org/10.26749/rstpp.131.21 ISSN 0080-4703. Department of Zoology, University of Tasmania, GPO Box 252-05, Hobart, Tasmania, Australia, Australia 7001 (AMMR, RS); and 8 Cedar Court, Glen Waverley, Victoria, Australia 3150 (VW).
\end{abstract}

The crustaceans and molluscs of 65 saltmarshes and brackish marshes around the coast of Tasmania and the major Bass Strait islands were surveyed. Over 50 species were collected, but only eight (three talitrid amphipods, one crab and four gastropods) were confined to saltmarshes; the typical saltmarsh assemblage consisted of two talitrid amphipods, three oniscoid isopods, two crabs, two prosobranch snails and two pulmonate snails. The greatest species richness was found in marshes from the southeast and the far northwest, where the most extensive saltmarshes have developed. Several undescribed talitrids were collected and the range of two coastal species was extended significantly. The native woodlouse Plymophiloscia ulverstonensis was commonly found on the upper parts of the marshes, as was the introduced slater Porcellio scaber. The burrowing grapsid crab Helograpsus haswellianus was common on the marshes, though it was replaced by the ocypodid Heloecius cordiformis in brackish marshes, and by another grapsid, Paragrapsus gaimardii, in the only marsh examined on King Island. The hymenosomatid crab Amarinus paralacustris was recorded from the state for the first time at Hendersons Lagoon. Amphibolid and ellobiid snails typified the molluscan fauna of the marshes. The introduced ellobiid Phytia myosotis appears to have a major disjunction in its distribution between the southeast and northern sites.

Tasmanian saltmarshes have a similar diversity of crustaceans and molluscs to those of New Zealand and South Africa. They are richer in species than saltmarshes of the northeast Atlantic coasts but have fewer crustaceans than the temperate east coast marshes of North America, and fewer molluscs than those of the coasts of the Pacific northwest.

Keywords: salt marshes, diversity, Amphipoda, Isopoda, crabs, Gastropoda, Tasmania.

\section{INTRODUCTION}

Despite the ubiquity of saltmarshes in southern temperate Australia, their fauna has received surprisinglylittleattention. The only published work on the fauna of an Australasian saltmarsh (Paviour-Smith 1956) deals with a marsh in the South Island of New Zealand, while an unpublished thesis (Marsh 1982) describes the fauna of a saltmarsh on the Derwent River in southern Tasmania. The paper presented here describes the crustacean and molluscan fauna of saltmarshes around the coast of Tasmania and the major Bass Strait islands.

Saltmarshes are, by definition, areas bordering sheltered saline waters, vegetated by herbs, grasses or low shrubs. They are exposed to the air for most of the time but are subject to periodic flooding as a result of tidal or non-tidal fluctuation of the adjacent water body (Adam 1990). Tidal submergence distinguishes coastal saltmarshes from terrestrial habitats, and the absence of tall woody plants distinguishes saltmarshes from mangroves, the other major type of tidal vegetation (Adam 1990).

In many estuaries, there is a continuum between coastal, saline marshlands and marshlands in the upper estuary that are subject to tidal but non-saline flooding (Adam 1990), creating a problem of definition. In this study, the succulent ground-covering herb Sarcocornia quinqueflora was used to indicate saltmarsh, since it is restricted to wet and saline habitats not subjected to prolonged inundation (Waisel 1972); of all the saltmarsh species it is the most tolerant of high salinity (Patton 1942) and poor drainage (Kirkpatrick \& Glasby 1981), and does not grow in water of low salinity. Nevertheless, a number of brackish marsh sites which lacked S. quinqueflora were included in this study, since their faunal communities differ both from those of true saltmarshes and from those of fteshwater marshes
(Odum 1988), and yet they represent part of the sea-toland transition.

The Tasmanian coastline is diverse, ranging from the very exposed shores of the west coast to the dissected, sheltered coastline of the southeast. There are several large marine inlets, Macquarie Harbour, Port Davey/Bathurst Harbour and the Derwent and Tamar estuaries. Saltmarshes have developed in a variety of sheltered locations in Tasmania; they range in size from sites of many hectares, extending along kilometres of shoreline, to narrow bands a few hundred metres long or less. The flooded river valleys and estuaries of the Bass Strait and east coasts support significant ateas of saltmarsh, but the sheltered shores of the indented south east coast and the far west of the north coast support the largest areas. On the west and south west coast, the major inlets of Macquarie Harbour and Port Davey/Bathurst Harbour provide sheltered conditions, and saltmarshes have formed there. True saltmarshes do not occur on high energy coasts, but similar plant communities can be found where saltwater accumulates along rocky coasts, as a result of spray or occasional inundation by the sea (Kirkpatrick \& Glasby 1981). One such community on the west coast was examined in this study.

The fauna of saltmarshes can be divided into four major ecological groups: marine, freshwater, semiterresttial and terrestrial (Adam 1990). When the aquatic species, which have a much wider habitat range than the water in and around saltmarshes, are eliminated, the species which remain are those that inhabit the marsh surface (Daiber 1977); it was these species that we chose to sample in this survey. Crustaceans and molluscs dominate this fauna, and they are likely to be the most important groups in these decomposition-based systems. Marsh (1982) found that the dominant saltmarsh animals in southeast Tasmania were crabs, gastropods, coccid Hemiptera and mites. All 
these groups can be considered important by reason of their abundance or biomass (Subrahmanyam et al. 1976), but herbivorous insects are unlikely to play a major role in the marsh ecosystem, since levels of herbivory in saltmarshes are low (Teal 1962), probably because of the poor nutritional status of the vegetation (Adam 1990). In contrast, detritivores are of considerable importance in energy and nutrient flows (Adam 1990) and in structuring the saltmarsh environment through their burrows (Marsh 1982). Thus, we chose to survey snails, amphipods, isopods and crabs as the most abundant and important components of the terrestrial fauna. These elements of the fauna also have the advantage of being available to be surveyed at all seasons of the year.

In this paper, we describe the crustacean and molluscan fauna of Tasmanian saltmarshes and record the distribution of the species in these groups. While the distribution of the molluscan fauna has received some incidental attention (Smith \& Kershaw 1981), the intertidal crustacean assemblages are almost entirely unstudied. Griffin (1971) described the ecological ranges of the crabs of southeast Tasmania, Richardson \& Marsh (in press) described the ecological ranges of talitrid amphipods at Lutregala Marsh on Bruny Island, and some ecological and distributional notes were provided in the taxonomic studies of the oniscoid isopods by Green (1961).

\section{METHODS}

In order to cover as wide a range of habitats as possible, our sampling regime was based on the vegetation communities in each marsh, because these represent plant species assemblages, which in turn reflect the soil conditions, i.e. salinity and drainage (Kirkpatrick \& Glasby 1981, Partridge \&Wilson 1989). Saltmarshes have been traditionally viewed as having three zones between sea and land (Adam 1990): the low marsh - the area which is inundated by every tide; the mid marsh - the area which is inundated by most tides; and the high marsh - the area which is very rarely inundated. These three zones do not have distinct boundaries but usually can be distinguished by a change in the vegetation community or its understorey. Within each saltmarsh zone, we identified three broad vegetation types:

(1) a ground-covering succulent and herbaceous community, characterised by Sarcocornia quinqueflora, Samolus repens, Hemichroa pentandra, Selliera radicans, Wilsonia backhousei, Sarcocornia blackiana and Pucciniella stricta;

(2) a salt bush community, characterised by Arthrocnemum arbuscula; and

(3) a grass/sedgeland community, characterised by Stipa stipoides, Poa labillardieri, Juncus krausii and/or Gabnia filum, Leptocarpus brownii, or Spartina townsendii.

Some saltmarsh plants extend over more than one of these tidal zones. Sarcocornia quinqueflora, for example, is able to grow in all three. This system of plant community classification encompasses all the vegetation communities defined by Kirkpatrick \& Glasby (1981). We sampled four replicate quadrats from each vegetation community within each of the three zones defined above. In the marsh midzone, there were sometimes two distinctly different grass/ sedge communities, most commonly dominated by Gahnia filum or Stipa stipoides, reflecting different soil conditions
(Kirkpatrick \&x Glasby 1981) and having different morphologies. In such cases, both communities were sampled independently.

In each vegetation zone, quadrats were located so that the samples represented a range of heights within the category and zone, and encompassed the whole range of plant species within the vegetation community. The quadrats were $0.5 \times 0.5 \mathrm{~m}^{2}$ in area, and from each one amphipods, isopods and snails were collected by hand or with an aspirator, then preserved in $70 \%$ alcohol. An estimate of the total numbers of individuals of each species was made and the number of crab burrows (i.e. burrow systems, not burrow openings) was recorded. In order to find as many of the species present in each quadrat as possible, the vegetation was thoroughly searched, which often involved teasing apart grass tussocks, pulling up plants at the roots (since amphipods sometimes follow these down into the soil) and overturning mosses and logs. Crabs were sampled by digging up a number of burrows within a quadrat and from mudflats within the saltmarshes.

The size of quadrats used was a compromise necessitated by the wide range in the size and abundance of the species being sampled. Because they were stratified by vegetation type, the number of quadrats sampled at each site depended on the complexity of the vegetation, and ranged from four (Granville Harbour, Policemans Point, New River North) to 24 (Stanley West Inlet). Species accumulation curves for the data from Stanley West Inlet, where 24 quadrats were collected, showed that, even in the worst case, $90 \%$ of species were collected after 12 quadrats had been examined. Seventeen sites were sampled with 8 quadrats or fewer, so it is possible that the species richness at those sites may have been underestimated.

The animals collected were identified, using the following resources: amphipods - A.M.M. Richardson (unpublished key); terrestrial molluscs - Smith \& Kershaw (1981); marine molluscs - Macpherson \& Gabriel (1962) (nomenclature follows changes published in the Zoological Catalogue of Australia (Smith 1992)); isopods - Green (1961) and Hopkin (1991); crabs - Campbell and Griffin (1966) and Westcott (1976).

\section{RESULTS}

In total, 65 marshes were investigated, 52 of which were saltmarshes, the rest being brackish marshes or at the mouths of rivers. Figure 1 shows the locations of the sample sites.

Over 50 species of crustaceans and molluscs were collected, but only eight of these have distributions that are effectively confined to saltmarshes: the amphipods Eorchestia palustris and two undescribed Eorchestia spp., the snails Ophicardelus ornata, Salinator solida, Phytia myosotis and Hydrococcus brazieri, and the crab Helograpsus haswellianus. The most common crustaceans and molluscs in Tasmanian saltmarshes are the marsh-hopper Eorchestia palustris and the beachflea Orchestia australis, the snails Salinator solida, Ophicardelus ornata, Hydrococcus brazieri and Tatea rufilabris, the isopods Ligia australiensis, Deto marina and Porcellio scaber, and the crabs Helograpsus haswellianus and Paragrapsus gaimardii.

The saltmarshes with the greatest diversity of crustaceans and molluscs were Hildyard Point, in Blackman Bay on the east coast (19 species), Lauderdale, in the Derwent estuary (17 species), Long Point, on the west coast of 


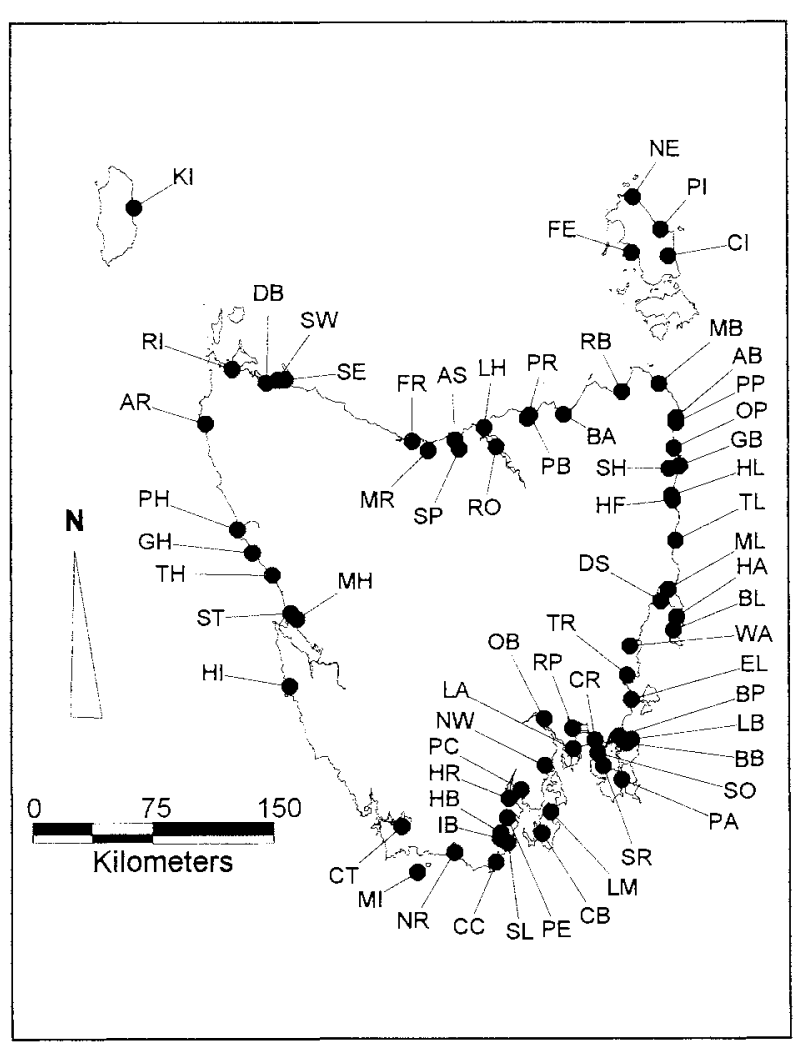

FIG. 1 - Location of sampling sites. Site codes are as follows. $A B-A n s o n s$ Bay, north side; $A R-A r t h u r$ River, marsh near mouth; $A S$ - Asbestos National Park; BA - Andersons Bay, Trent Water; BB - Blackman Bay, Forestier Peninsula; $B L$ - Bryans Lagoon, Freycinet Peninsula; BP - Hildyard Point, Blackman Bay; CB - Cloudy Bay Lagoon, Bruny Island; CC-Cockle Creek; CI - Cameron Inlet, Flinders Island; $C R$-Carlton River; $C T$-Celery Top Island, Bathurst Harbour; DB - Duck Bay, Smithton; DS - Dolphin Sands Road, Moulting Lagoon; EL - Earlham Lagoon; FE - Long Point, Flinders Island; FR - Forth River; GB - Georges Bay; GH - Granville Harbour; HA - Hazards Lagoon, Freycinet Peninsula; $H B$ - Hastings Bay, Southport; HF-Hendersons Lagoon, Falmouth; HI - Hibbs Lagoon; HL - Hendersons Lagoon, Scamander; HR - Huon River, Surges Bay; IB - Ida Bay, Southport; KI - King Island, Sea Elephant River; LA - Lauderdale, Ralphs Bay; LB - Swan Lagoon, Tasman Peninsula; $L H$ - Low Head, Tamar River; $L M$ - Lutregala Marsh, Bruny Island; $M B$ - Musselroe Bay; $M H-$ Macquarie Harbour; $M I$ - Maatsuyker Island; $M L-$ Moulting Lagoon, road to Coles Bay; $M R$ - Mersey River; $N E-N o r$ theast River, Flinders Island; NR - New River Lagoon; NW-North West Bay; OB - Old Beach, Derwent River; OP - Sloop Lagoon; $P A$ - Port Arthur; PB - Pipers Brook, Pipers River; $P C$ - Port Cygnet; PE - Port Esperance; PH - Pieman Heads; PI - Patriarch Inlet, Flinders Island; PP - Policemans Point, Ansons Bay; PR - Pipers River; RB - Ringarooma Bay; $R I$ - Coast opposite Robbins Island; RO - Rowella, Tamar River; RP - Railway Point, Pittwater; SE - Stanley, East Inlet; SH - St. Helens; SL - Southport Lagoon; SO - Sloping Lagoon; SP - Port Sorell, south east arm; SR - Saltwater River; ST-Strahan; SW-Stanley, West Inlet; TH - Trial Harbour; TL - Templestowe Lagoon; TR - Triabunna; WA - Little Swanport.
Flinders Island (15 species), Lutregala Marsh, on the Bruny Island isthmus ( 15 species), a marsh in the far northwest opposite Robbins Island (15 species) and West Inlet at Stanley (15 species).

Analysis of the species richness at each site (fig. 2) shows that the richest sites are generally in the indented coastline of the southeast, in the inlets of the north coast, or in the far northwest. The west coast, in contrast, has only two sites with five or more species.

The distribution and abundance of species in each of the major groups is discussed below.

\section{Amphipoda}

The Talitridae is the only family of terrestrial amphipods; 20 described or undescribed species from this family were collected, though some were very rare (table 1 ). The taxonomy of the intertidal talitrids is unsatisfactory, and few species from what is apparently a diverse fauna have so far been described (Richardson 1993, 1996). Because of this, informal names have been used for undescribed species or where generic placements are uncertain; formal taxonomic descriptions of these species are being prepared (Richardson, pers. obs.). Species have also been classified into Bousfield's (1982) and Friend's (1987) loose phylogenetic or ecological groupings: i.e. the marsh hoppers - plesiomorphic forms found in the wettest saltmarsh habitats; beachfleas - nonsubstrate-modifying species which are found on most muddy

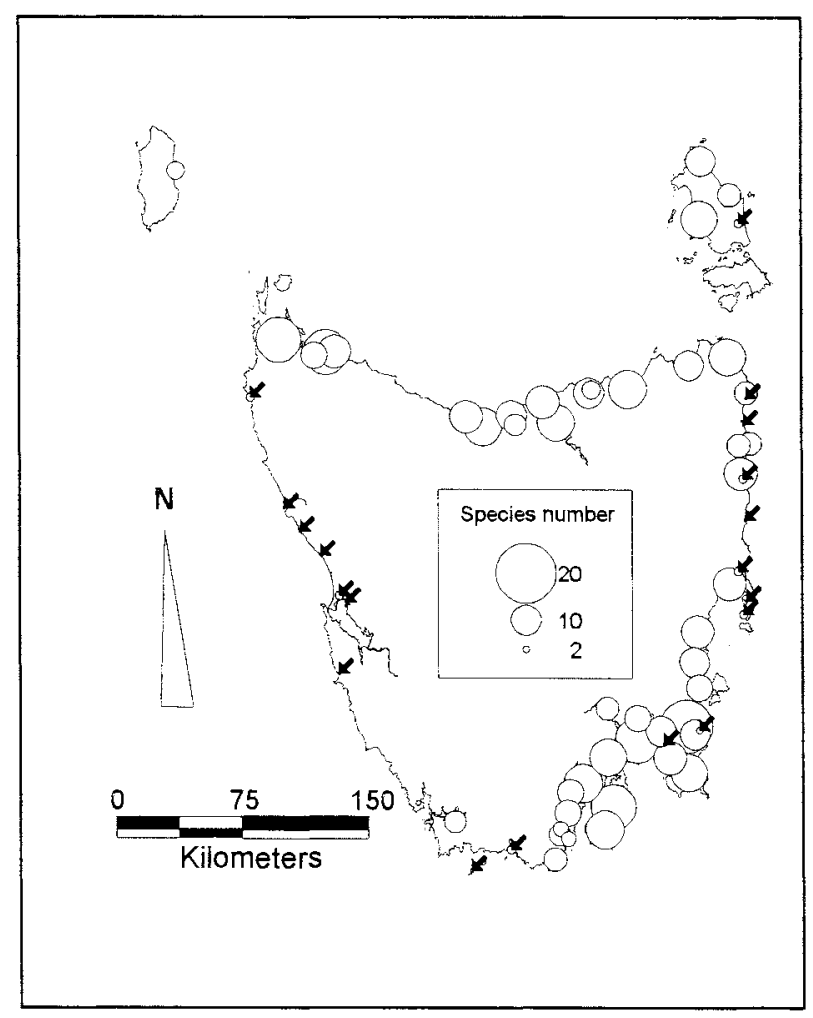

FIG. 2 - Species richness in the saltmarshes. The sizes of the circles are proportional to the number of species collected at each site. Arrows mark sites where fewer than five species were collected. 
TABLE 1

Talitrid amphipods collected from Tasmanian saltmarshes

\begin{tabular}{|c|c|}
\hline $\begin{array}{l}\text { Morphological groupings } \\
\text { (after Bousfield 1984)* }\end{array}$ & $\begin{array}{l}\text { Ecological Groupings } \\
\text { (after Friend 1987)* }^{*}\end{array}$ \\
\hline \multicolumn{2}{|l|}{ Group la (palustrals) } \\
\hline Eorchestia palustris Richardson, 1993 & Marsh-hopper \\
\hline E. rupestris Richardson, 1993 & Marsh-hopper \\
\hline$E$. n.sp. 1 Earlham Lagoon & Marsh-hopper \\
\hline E. n.sp. 2 Rowalla & Marsh-hopper \\
\hline E. n.sp. 3 Flinders West Coast & Marsh-hopper \\
\hline \multicolumn{2}{|l|}{ Group 2 (beachfleas) } \\
\hline Orchestia australis Fearn-Wannan, 1968 & Beachflea \\
\hline Transorchestia "Lunawanna" & Beachflea \\
\hline "4-dentate beachflea" & Beachflea \\
\hline "4-dentate beachflea Old Beach" & Beachflea \\
\hline "4-dentare beachflea Granville Harbour" & Beachflea \\
\hline \multicolumn{2}{|l|}{$\begin{array}{l}\text { Group } 3 \text { (sandhoppers) } \\
\text { not recorded from saltmarshes }\end{array}$} \\
\hline \multicolumn{2}{|l|}{ Group $4 \mathrm{a}$ (cuspidactylate landhoppers) } \\
\hline Tasmanorchestia n.sp. 3 & Coastal landhopper \\
\hline Tasmanorchestia n.sp. 5 & Coastal landhopper \\
\hline \multicolumn{2}{|l|}{ Group 4b (simplidactylate landhoppers) } \\
\hline Austrotroides maritimus Friend, 1987 & Coastal landhopper \\
\hline Austrotroides n.sp. & Coastal landhopper \\
\hline Mysticotalitrus tasmaniae (Ruffo, 1949) & Forest landhopper \\
\hline M. cryptus Friend, 1987 & Forest landhopper \\
\hline Arcitalitrus bassianus Friend, 1987 & Coastal landhopper \\
\hline Keratroides vulgaris (Friend, 1979) & Forest landhopper \\
\hline K. pyrensis Friend, 1987 & Forest landhopper \\
\hline K. rex Friend, 1987 & Coastal landhopper \\
\hline
\end{tabular}

*Classified by Bousfield's informal scheme (Bousfield 1984) and Friend's ecological groups (Friend 1987). Work is in progress to describe the informally named species (beachfleas and marshhoppers - A.M.M. Richardson; landhoppers - J.A. Friend).

and rocky shores; and landhoppers - truly terrestrial species, which can be divided ecologically into coastal species, restricted to a zone close to the high water mark, and forest species, which extend hundreds of kilometres inland and to high altitudes.

Apart from one landhopper, Arcitalitrus bassianus, and one beachflea, Orchestia australis, all the described species of amphipods were Tasmanian endemics, but it will not be possible to make a complete assessment of the endemicity of the Tasmanian talitrid fauna until the fauna of south east Australia as a whole is better known. The distributions of these species are shown in figure 3A-D.

The marsh-hoppers (fig. 3A) are the only amphipods that are largely restricted to salt and estuarine marshes, although one marsh-hopper, Eorchestia rupestris, is also found on sheltered rocky shores on the east coast (Richardson 1993). Species in the genus have an almost statewide distribution and E. palustris is common in saltmarshes on all but the west and south coasts; it was not collected on Flinders or King Island. Eorchestia spp. are only found in areas of the saltmarshes that are subjected to regular tidal submergence, but their distribution on the marshes may include the lower emergent regions, where they overlap with the beachflea, Orchestia australis, which occupies the mid and upper, less-frequently inundated,
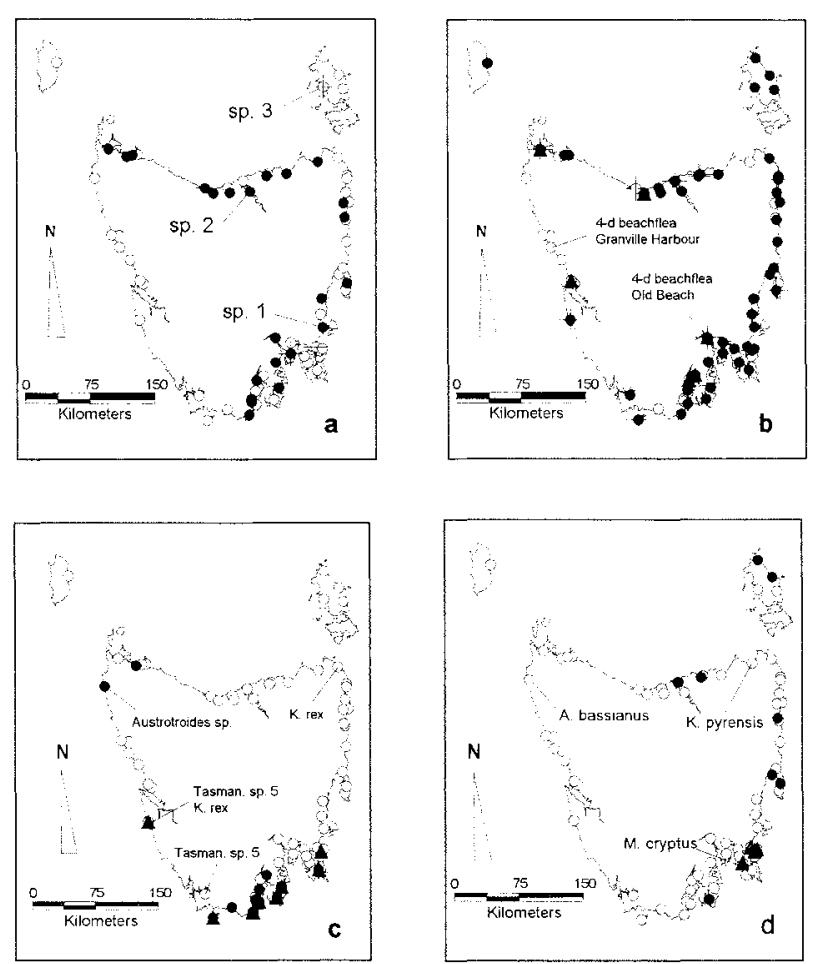

FIG. 3A-D - Distribution of amphipods on Tasmanian saltmarshes. Collecting sites are marked by open circles. (A) Marsh-hoppers. Closed circles - Eorchestia palustris; crosses - E. rupestris. (B) Beachfleas. Closed circles - Orchestia australis; triangles - Transorchestia "Lunawanna"; crosses "4-dentate beachflea". (C) Coastal landhoppers. Closed circles - Tasmanorchestia n.sp. 3; triangles - Austrotroides maritimus. (D) Forest landhoppers. Closed circles Keratroides vulgaris; triangles - Mysticotalitrus tasmaniae.

areas. Cockle Creek was the only site where E. palustris cooccurred with both $O$. australis and coastal landhoppers. In the saltmarshes at Duck Bay, Ringarooma Bay, Hastings Bay, Huon River, Forth River, Ida Bay, Hendersons Lagoon (Scamander) and St Helens, Eorchestia spp. were the only supralittoral talitrids present. These sites are all reedy, submergent marshes, where the entire marsh is subjected to very regular inundation, and they are located at the heads of marine inlets and estuaries.

Of the two described species of Eorchestia, the small marsh-hopper $E$. palustris is widespread but apparently absent from the Tasman Peninsula, where E. rupestris, a larger marsh-hopper, is found in saltmarshes. The distribution of E. rupestris, as recorded in this study, appears to be very disjunct. It was found in southeast Tasmania from Lauderdale and Blackman Bay, and also from the saltmarsh on the west coast of Flinders Island, but it is also found on sheltered rocky shores between these localities (Richardson 1993).

Three undescribed forms of Eorchestia were collected, from three separate localities: the west coast of Flinders Island, Eartham Lagoon, and Rowella on the Tamar River. From each of these localities only very small numbers of individuals were found, and they co-occurred with much larger numbers of $E$. palustris.

The beachflea Orchestia australis is the most numerous and common amphipod in saltmarshes in Tasmania 
(fig. 3B). It was found at 46 of the 52 saltmarsh sites on all coasts and occupies a wide range of habitats from the lower marsh to the landward reaches. It is also found in many other supralittoral habitats. At five sites (northwest coast opposite Robbins Island, Low Head, Pipers River, Bryans Lagoon and Southport Lagoon), it co-occurs with a fourdentate beachflea that is apparently morphologically identical except for the dentition of its left mandibular lacinia mobilis, a character of considerable phylogenetic significance (Bousfield 1982). Two other undescribed fourdentate beachfleas were found, one in the marsh-like vegetation above the rock platforms at Granville Harbour and the other in the estuarine marsh at Old Beach (a single individual only).

The beachflea Transorchestia "Lunawanna" is distributed patchily around the state. It is found in the Derwent and Huon Rivers, on Bruny Island, at Strahan, in the Forth River and on the northwest coast opposite Robbins Island. Although this distribution appears to be disjunct, it merely reflects the species' presence in other non-saltmarsh habitats (A.M.M. Richardson, pers. obs.).

The other amphipods found in Tasmanian saltmarshes are landhoppers of either the coastal (fig. 3C) or forest (fig. 3D) groups of Friend (1987). They are found in the upper marsh regions, areas which are rarely inundated, and a habitat that is essentially terrestrial, rather than intertidal or supralittoral. The coastal landhoppers Austrotroides maritimus and Tasmanorchestia spp. were restricted to the west, south and southeast coast. The other coastal landhopper collected, Keratroides rex, appeared in samples from only two localities, Hibbs Bay and Musselroe River, though it has been widely collected in non-marsh coastal habitats from South East Cape west to the Tamar River (Friend 1987). Of the forest landhoppers, Mysticotalitrus tasmaniae was found only on the Tasman Peninsula and at Blackman Bay. Landhoppers occurred in large numbers on the marshes at Cockle Creek, Port Esperance, Cloudy Bay, Port Arthur, Celery Top Island, Southport Lagoon, Hildyard Point, Salrwater River and Lutregala Marsh. Most of these sites are from relatively high rainfall areas with mostly undisturbed forest inland of the saltmarsh, except for Port

TABLE 2

Isopods collected from Tasmanian saltmarshes

\author{
Family LIGIIDAE \\ Ligia australiensis Dana, 1853 \\ Family STYLONISCIDAE \\ Styloniscus sp. \\ Family ONISCIDAE \\ Scyphacinae \\ Deto marina (Chilton, 1884) \\ Philoscinae \\ Plymophiloscia ulverstonensis Green, 1961 \\ Family ARMADILLIDAE \\ Cubaris sulcifrons Green, 1961 \\ Cubaris tamarensis Green, 1961 \\ Family PORCELLIONIDAE \\ * Porcellio scaber Latreille, 1804 \\ Family ARMADILLIDIIDAE \\ *Armadillium vulgare (Latreille, 1804)
}

\footnotetext{
* Introduced species.
}

Esperance and Saltwater River, where the backing vegetation has been largely cleared away for roads.

These collections significantly extend the ranges of some of the coastal landhoppers. Tasmanorchestia is now known not only from the west coast (Friend 1987), Bruny Island (Mulcahy 1990) and the northwest (Richardson et al. 1990), but also from the southeast and Tasman Peninsula. Mulcahy's records of Austrotroides maritimus (1990) from Bruny Island are confirmed and extended, while the range of Keratroides rex is extended from west of the Tamar (Friend 1987) to the far northeast at Musselroe Bay.

\section{Isopoda}

Eight species of isopod were collected from the saltmarshes sampled (table 2). All occur in other habitat types as well as saltmarsh (Green 1974). Cubaris tamarensis, C. sulcifrons and Plymophiloscia ulverstonensis are endemic to Tasmania (Green 1974), but Ligia australiensis and Deto marina are also found elsewhere in Australia. Armidillidium vulgare and Porcellio scaber are both introduced species, originating in the Mediterranean and the Atlantic region of Europe respectively (Green 1974).

Figure 4A-C shows the distributions of all these species in Tasmanian saltmarshes. Of the intertidal isopods (fig. 4A), Ligia australiensis is found principally on rocky shores; however, it occurs in saltmarshes on the north, east and south coasts, and on the Bass Strait islands. It does not
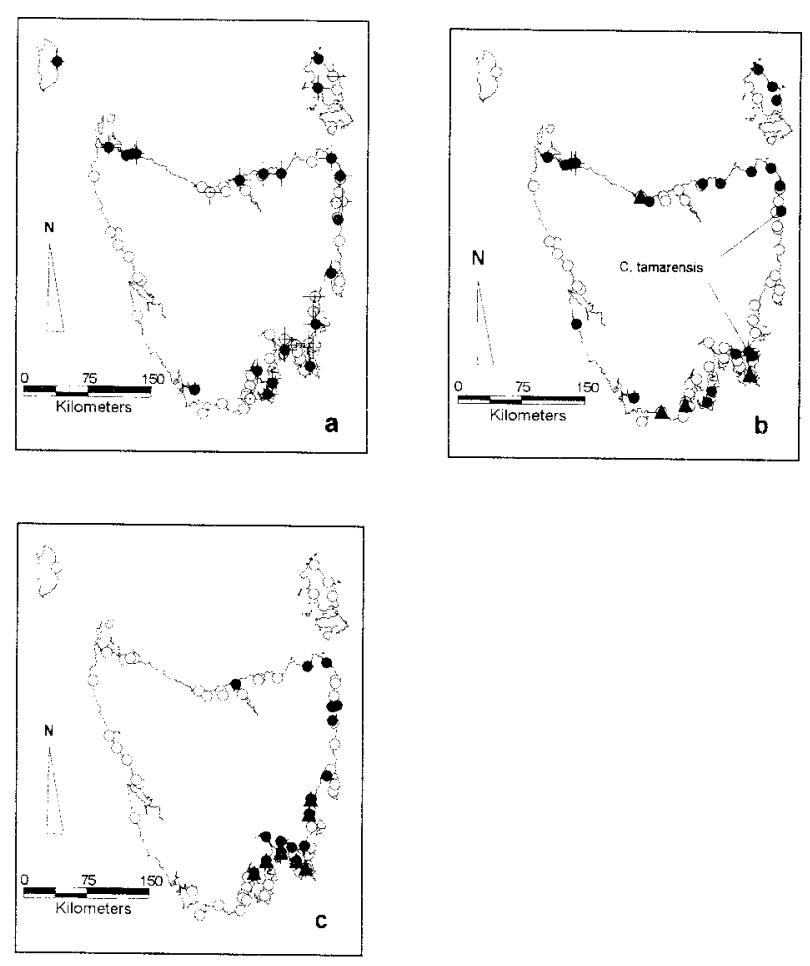

FIG. 4A-C-Distribution of oniscoid isopods on Tasmanian saltmarshes. Collecting sites are marked by open circles. (A) Sea slaters. Closed circles - Ligia australis; crosses - Deto marina. (B) Coastal slaters. Closed circles - Plymophiloscia ulverstonensis; triangles - Styloniscus sp.; crosses - Cubaris sulcifrons. (C) Introduced slaters. Closed circles - Porcellio scaber; triangles - Armidillidium vulgare. 
occur at the inlet sites, except at Bathurst Harbour. Deto marina has a similar distribution to $L$. australiensis, but occurs more often in sheltered inlets. D. marina appears to be the isopod that is best adapted to life in Tasmanian saltmarshes, as it is the only species that is distributed throughout the mid-marsh flat.

Among the native woodlice (fig. 4B), Plymophiloscia ulverstonensis is widely distributed, while the other native Cubaris and Styloniscus spp. occur patchily in saltmarshes. These species are all terrestrial woodlice, though some are apparently confined to the maritime zone (Green 1961). As in the landhoppers, some species of woodlice are known to have distributions closely tied to the coastline (Sutton \& Harding 1989, Hopkin 1991). It is likely that some of the woodlice collected in this study, e.g. $P$. ulverstonensis and the two Cubaris spp., have similar coastal distributions.

One of the introduced species, Armidillidium vulgare, is restricted to saltmarshes in the southeast, which may reflect its spread from a point of introduction in Hobart (fig. 4C). The other introduced species, $P$. scaber, is widely distributed on the east and north east coasts.

\section{Crabs}

The nine species of crabs collected are listed in table 3 , and their distributions in saltmarshes are shown in figure 5A-B. All these species of crab have been found in this habitat type previously (Griffin 1971). Although Griffin (1971) examined the local distributions of crabs in southeastern Tasmania in some detail, no statewide examination of the distribution of intertidal crab species appears to have been made.

Helograpsus haswellianus is the most common saltmarsh crab, but appears to be absent from the west coast and King Island (fig. 5A). It is often found over the entire marsh, in low, medium and high zones, living in complex burrows, which descend to the water table, and often have more than one entrance. The burrow density is greater in the lower and more frequently inundated marsh regions. Young individuats of $H$. haswellianus were found in the lower

TABLE 3

Crabs collected from Tasmanian saltmarshes, with their common names, where available

$\begin{array}{ll}\text { Family GRAPSIDAE } & \\ \text { Brachynotus spinosus } & \\ \text { (H. Milne-Edwards, 1853) } & \text { Little shore crab } \\ \text { Cyclograpsus granulosus } & \\ \text { (H. Milne-Edwards, 1853) } & \text { Smooth shore crab } \\ \text { C. audouinii H. Milne-Edwards, } 1837 & \\ \begin{array}{l}\text { Paragrapus gaimardii } \\ \text { (H. Milne-Edwards, 1837) }\end{array} & \\ \begin{array}{l}\text { P. laevis (Dana, 1852) } \\ \text { Helograpsus haswellianus (Whirelegge, 1889) Mud crab }\end{array} \\ \begin{array}{l}\text { Family OCYPODIDAE } \\ \text { Heloecius cordiformis }\end{array}\end{array}$

(H. Milne-Edwards, 1837)

Semaphore crab

Family HYMENOSOMATIDAE

Amarinus lacustris (Chilton, 1882)

A. paralacustris (Lucas, 1970) marsh and frontal mudflat areas. This species was not found on the most emergent or dry saltmarshes.

The second most common species, Paragrapsus gaimardii, is found all around the state (though it was not collected on Flinders Island), in the lower regions of the marsh and on the edge of creeks. In some instances, it is found in the mid regions of the marsh, but the more common species here is $H$. haswellianus. At one site (Sea Elephant River on King Is.) where $H$. haswellianus is absent, burrows of $P$. gaimardii cover the whole marsh area in a very complex and extensive network, similar to that found on the marshes dominated by $H$. haswellianus.

Heloecius cordiformis is found in the more brackish marshes. Griffin (1971) examined the habitat preferences of all species of Tasmanian grapsid and ocypodid crabs, and found, in laboratory experiments, that $H$. cordiformis has the least tendency to emigrate from freshwater to seawater. It lives on tidal mudflats in front of and interspersed throughout the saltmarsh. In these mudflats it co-exists in much greater density with $H$. haswellianus. The other crab species occurred in lower numbers in the low and frontal marsh areas.

The hymenosomatid genus Amarinus was collected from five localities (Fig. 5B). Material from all but one of these could be identified as $A$. lacustris. A single specimen from Hendersons Lagoon had the smaller female genital aperture and egg size that Lucas (1980) describes as characteristic of A. paralacustris. This species has not previously been recorded from Tasmania.

\section{Mollusca}

Gastropods were the most common molluscs found in Tasmanian saltmarshes. Twenty one species of snails and slugs were collected, and one species of bivalve (Mytilus sp.). The species collected are listed in table 4 and their distributions are shown in figure $6 \mathrm{~A}-\mathrm{D}$.

Figure 6A shows the distribution of the three commonest prosobranch species, Hydrococcus brazieri, Tatea rufilabris and Bembicium sp. These species are widely distributed except on the west coast and King Island; all are found in other saline habitats. Our collections fill in the range of Hydrococcus brazieri in the east of the state, compared to
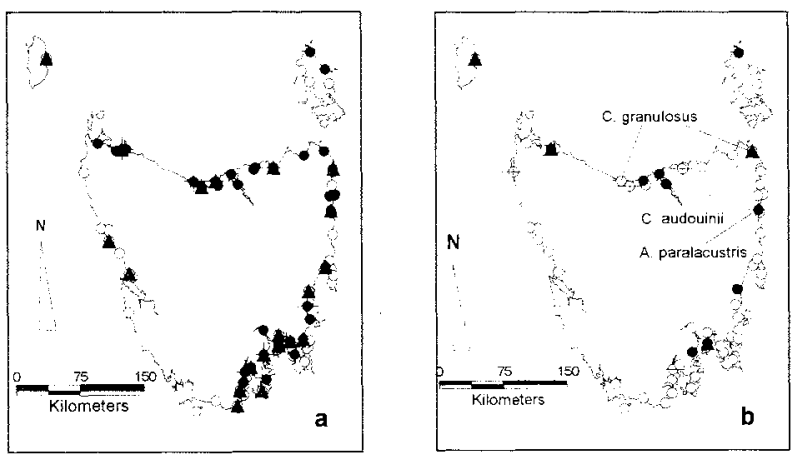

FIG. SA-B-Distribution of crabs on Tasmanian saltmarshes. Collecting sites are marked by open circles. (A) Common crabs. Closed circles - Helograpsus haswellianus; triangles Paragrapsus gaimardii; crosses -. Heloecius cordiformis. (B) Less-common crabs. Closed circles - Paragrapsus laevis; triangles - Brachynotus spinosus; crosses - Amarinus lacustris. 
Smith and Kershaw's records (1981), and extend its Tasmanian range to include Flinders Island. Our records extend the known range of $T$. rufilabris into the far northwest, but this species did not appear in our collections from Macquarie Harbour (cf. Smith \& Kershaw 1981). Truncatella scalarina and, hence, the Family Truncatellidae is now known from the southeast of the state at Blackman Bay and Carlton River, rather than being restricted to the north coast (Smith \& Kershaw 1981). Other prosobranch molluscs were collected (fig. 6B)and, at the seaward edges of saltmarshes, marine prosobranchs such as Austrocochlea spp. and terebrids often occurred.

Amphibious pulmonates in the families Ellobiidae, Ophicardelus ornata and Phytia myosotis, and Amphibolidae, Salinator solida, are highly characteristic of Tasmanian

\section{TABLE 4}

Molluscs collected from Tasmanian saltmarshes

\author{
Phylum MOLLUSCA \\ Class GASTROPODA \\ Subclass PROSOBRANCHIA \\ Order NOTAENIOGLOSSA \\ Family LITTORINIDAE \\ Bembicium sp. \\ Order MONOTOCARDIA \\ Family HYDROBIIDAE \\ Tatea rufilabris (Adams, 1862) \\ Family TRUNCATELLIDAE \\ Truncatella scalarina Cox, 1867 \\ Family ASSIMINEIDAE \\ Assiminea buccinoides (Quoy \& Gaimard, 1835) \\ Family HYDROCOCCIDAE \\ Hydrococcus brazieri (Tennison-Woods, 1876) \\ Order NEOGASTROPODA \\ Family TEREBRIDAE
}

Subclass PULMONATA

Order BASOMMATOPHORA

Family ELLOBIIDAE

*Phytia myosotis (Draparnaud, 1801)

Ophicardelus ornata (Ferussac, 1821)

Family AMPHIBOLIDAE

Salinator solida (van Martens, 1878)

Order SIGMURETHRA

Family RHYTIDIDAE

Tasmaphena sinclairi (Pfeiffer, 1845)

T. ruga (Legrand, 1871)

Prolesophanta nelsonensis (Brazier, 1871)

Family ARIONIDAE

*Arion intermedius Normand, 1852

Family SUCCINEIDAE

Succinea australis (Ferussac, 1821)

Family LIMACIDAE

* Deroceras reticulatum (Muller, 1774)

${ }^{*}$ Deroceras spp.

Family HELICIDAE

${ }^{*}$ Cochlicella barbara (Linnaeus, 1758)

*Helix aspera Muller, 1774

Class BIVALVIA

Family MYTILIDAE

Xenostrobus securis (Lamark, 1819)

* Introduced species. saltmarshes (Figure 6C). Ophicardelus ornata is found all around the state, apart from the west coast. Our records of it are apparently the first from Flinders Island. Its absence from the Derwent River region (represented by the Old Beach and Lauderdale sites), which would seem to be suitable habitat, is surprising. This species has a marshwide distribution, ranging from the submergent Sarcocorniaand Juncus-dominated vegetation, through the mid marsh into the more terrestrial reed/grass vegetation; it often shows a very clumped distribution pattern. Our records of the disjunct distribution of the Mediter ranean and Eastern Atlantic species Phytia myosotis parallel those of Smith \& Kershaw (1981) almost exactly (Stanley, central north coast, Flinders Island and Storm Bay). Climo (1982) suggests that this species was dispersed as egg capsules deposited on the hulls of wooden boats or on deck cargo that had come in contact with the saltmarsh fauna. Since these opportunities have become much rarer with the advent of steel hulls and constructed harbours, the present distribution of P. myosotis may reflect points of introduction early in the history of European settlement, from which the species can now only disperse very slowly.

Salinator solida is the most widely distributed saltmarsh gastropod, occurring throughout saltmarshes in all zones. Our collections extend Smith \& Kershaw's (1981) records
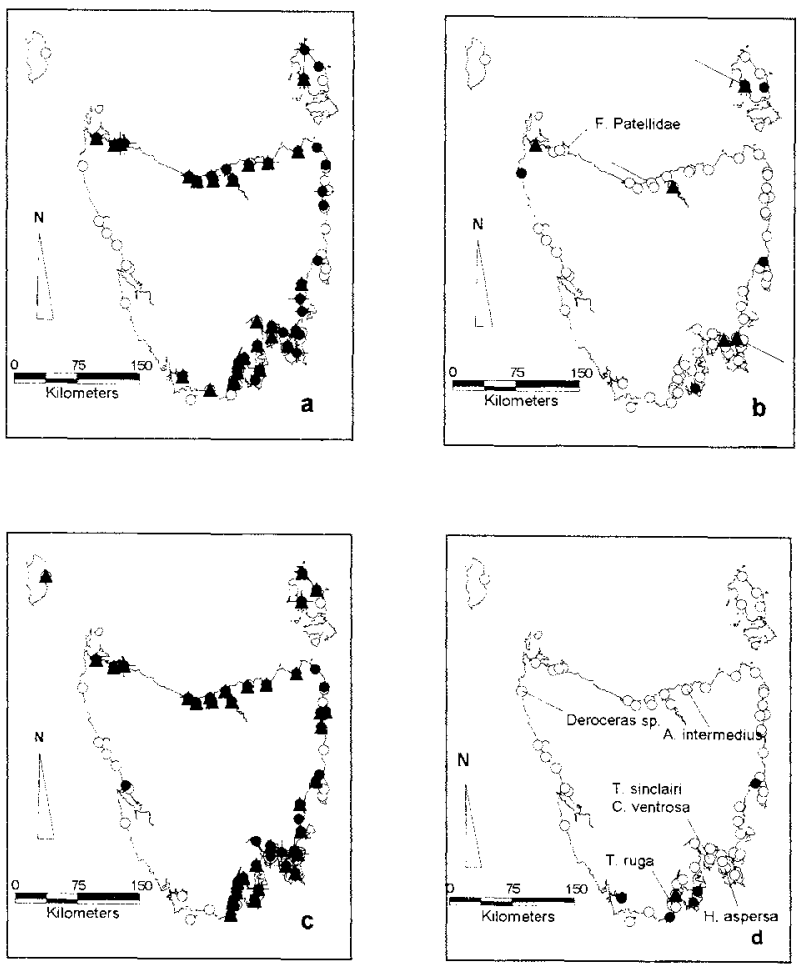

FIG. 6A-D - Distribution of gastropods on Tasmanian saltmarshes. Collecting sites are marked by open circles. (A) Common prosobranchs. Closed circles - Hydrococcus brazieri; triangles - Tatea rufilabris; crosses - Bembicium sp. (B) Less-common prosobranchs. Closed circles - Assiminea buccinoides; triangles - Truncatella scalarina; dashes F. Terebridae. (C) Amphibious pulmonates. Closed circles Salinator solida; triangles - Ophiocardelus ornata; crosses Phytia myosotis; large open circles - Succinea australis. (D) Terrestrial snails and slugs. Closed circles - Prolesophanta nelsonensis; triangles - Deroceras reticulatum. 
to cover the whole east coast. S. solida belongs to the family Amphibolidae, of which there are two species in Tasmania. This is the only pulmonate family with an operculum, an adaptation to life on land which allows the animal to seal its shell and so reduce water loss. This snail appears to be able to withstand extreme physical conditions, from submersion in saltwater to extended periods of desiccation, and so it can be considered to be well-adapted to life in the saltmarsh.

At the upper edges of saltmarshes and in backing vegetation, native forest snails (Tasmaphena sinclairi, T. ruga and Prolesophanta nelsonensis) were collected in small numbers (Figure 6D). In the same upper zone, the introduced slugs and helicid snails appeared, but none were numerous or widespread.

\section{DISCUSSION}

The Tasmanian coastline provides a wide range of conditions of exposure and topography. The faunal diversity of the marshes reflects those areas where marshes have developed most extensively: in the indented, sheltered coast of the southeast and in the northwest, where sheltered shores and flat hinterland have allowed extensive saltmarshes to develop. Kirkpatrick \& Glasby (1981) noted that several plant species were absent from the saltmarshes of the west and south coasts, and that others were confined to the southeast, east or northeast. A similar pattern appears in the crustacean and mollusc fauna, since several species are rare or absent on the west coast. Two factors which are likely to have contributed to this pattern are the cooler wetter climate in the west and the relatively poor development of saltmarsh there.

Apart from Marsh's (1982) localised study there have been no other faunal surveys of the Tasmanian saltmarsh fauna. Because of the lack of published work, it is difficult to put the diversity of the fauna of Tasmanian saltmarshes into a local context. It is likely that the general composition of the fauna of saltmarshes in mainland southeastern Australia is similar, since several gastropods recorded in Tasmanian marshes are also found there: Tatea rufilabris, Ophicardelus ornata, Phytia myosotis and Salinator solida (Smith \& Kershaw 1981). The southeastern Australian marshes are also floristically similar (Kirkpatrick \& Glasby 1981). Paviour-Smith (1956) recorded three species of talitrid amphipods, unidentified isopods and a grapsid crab but, apparently, no molluses from a saltmarsh in the South Island of New Zealand, but it would be unwise to base any general conclusions about the faunal diversity of New Zealand saltmarshes on this single site.

Macnae (1957) described the saltmarsh fauna of the Zwartkops estuary which enters Algoa Bay just north of Port Elizabeth, South Africa. In the supralittoral fringe and the midlittoral, he recorded three talitrid amphipods (Talorchestia australis, T. ancheidos and Parorchestia rectipalma) and a melitid amphipod (Melita zeylanica), two isopods (Tylos capensis and a Philosiciasp.) and three species of crab (Sesarma catenata, Cleistostoma edwardsi and Cyclograpsus punctatus). The molluscan assemblage comprised the hydrobiid Assiminea bifasciata and a small unidentifed pulmonate at the supralittoral fringe, and Littorina knysnaensis, Cerithidea decollata and Assiminea bifasciata in beds of Spartina stricta.

North American saltmarsh faunas have been described in general terms by Daiber (1982). The molluscan fauna of marshes on the Atlantic seaboard typically includes the ribbed mussel Geukensia demissa and, in southern marshes, the marsh clam Cyrenioda floridana. The typical saltmarsh snails are the ellobiid Melampus bidentatus in the upper regions and the littorinid Littoraria irrorata lower on the marshes. The crustacean fauna is dominated by fiddler crabs, Uca spp., and other species, such as Sesarma cinereum, S. reticulatum, Panopeus herbsti and Eurytium limosum. The talitrid amphipod fauna includes Uhlorchestia uhleri, Orchestia platensis, O. grillus and O. gammarella (Bousfield 1973). The oniscoid isopod Philoscia vittata is abundant in New England saltmarshes (Dexter 1947).

The typical crustacean and molluscan assemblage of saltmarshes on the northeast coast of the Atlantic is described by Nichol (1936) and Healey (1975). The non-aquatic crustaceans consist of the beachflea Orchestia gammarella, woodlice, including Porcellio scaber, Armidillidium vulgare, Philoscia muscorum and (in Ireland) Eluma purpurascens, and a single crab, Carcinus maenas. The molluscs typically include ellobiids such as Phytia (= Ovatella) myosotis, the high-shore winkle Littorina saxatilis and smaller species such as Phytia modesta.

Very few studies have examined regional variation in the invertebrate faunas of saltmarshes elsewhere in the world. MacDonald (1969) surveyed the molluscan fauna of marshes and tidal creeks on the North American Pacific coast, recording over 70 species, but only five of these were consistently common on the marshes. He distinguished two zoogeographical regions at a scale extending over almost $25^{\circ}$ of latitude, the Californian south of Point Conception and the Oregonian to the north. The study described here does not extend over such a large latitudinal scale, and the zoogeographic patterns which we have observed are explicable in terms of climatic differences between the west and east coasts, and the coastal topography, insofar as it affects the areal extent of individual marshes.

Our records of talitrid amphipods support the remarkable diversity of this group in Tasmania, already noted in other habitats (Friend 1987, Richardson et al. 1991, Richardson 1993, 1996). Only in New Zealand does a comparable diversity of species occur (Hurley 1957, Duncan 1994), but that fauna apparently lacks simplidactylate landhoppers. Two factors make saltmarshes the most probable habitat in which the evolution of the terrestrial habit in amphipods occurred: the very gradual transition from sea to land, and the presence of detritus from salt-adapted angiosperms in the intertidal zone (Richardson \& Mulcahy 1996). Tasmania's diverse talitrid fauna, which includes examples of all the known phylogenetic and ecological groups, and the abundance of saltmarsh habitat provide a valuable opportunity to study the process of adaptation to land in one of only two crustacean groups to have made this major evolutionary transition successfully. This can be best done at sites where saltmarshes are backed by native vegetation that supports landhopper populations (i.e. wet forest), but such sites are becoming rare as the coastal zone is cleared (Richardson et al., in press). A similar range of species with increasingly terrestrial adaptations is seen in the oniscoid isopods and the gastropods. In both groups, this study has revealed a range of species spanning the intertidal zone but, in these cases, several families are involved, compared to the single family of the Talitridae.

The common ellobiid snail of Tasmanian saltmarshes, Ophiocardelus ornata, appears to be the ecological equivalent of other saltmarsh ellobiids which have been well-studied 
in other parts of the world. In North America, Melampus bidentatus is the dominant snail in saltmarshes of the east coast (Little 1990). M. bidentatus occupies the mid/upper areas of marshes which are covered by water $2-4 \%$ of the time. It can live submerged in water for several days, but it can also can tolerate the loss of up to $80 \%$ of its body water and then rehydrate rapidly afterwards. In Europe, the commonest saltmarsh pulmonate is the ellobiid Phytia (=Ovatella) myosotis, which shows many physiological parallels with Melampus, including the ability to withstand a change in the salt concentration from freshwater to a salinity of nearly three times seawater (Little 1990). Ecophysiological studies on $O$. ornata may reveal similar adaptations; however, virtually nothing is known of this species.

Ellobiid snails are true saltmarsh species, one of the few groups of animals inhabiting their mid regions and, hence, are of particular interest, because their characteristics represent a state similar to that in the primitive ancestors of the true land snails, the Stylommatophora. Saltmarsh ellobiids are the most primitive of their family. They have successfully adapted to the harsh "barrier zone" at the top of the saltmarsh, and Little (1990) believes that little more than behavioural changes would be needed to adapt them to a terrestrial existence; indeed, some of the Ellobiidae have already become terrestrial. The existence of these snails in saltmarshes suggests that, as for the landhoppers, this may be one of the parhways along which snails have evolved from sea to land (Little 1990).

This study has shown that the crustacean and mollusc fauna of Tasmanian saltmarshes is diverse and interesting, and the habitat provides many opportunities for further ecological and physiological studies.

\section{ACKNOWLEDGEMENTS}

We are grateful to Adrienne Eberhard for assistance on field trips, to Professor Jamie Kirkpatrick for helpful discussions on saltmarsh flora, and to Dr Brian Smith for advice about mollusc taxonomy. Thanks to the Parks and Wildlife Service of the Tasmanian Department of Environment and Land Management for access to reserves. This study was funded by the National Estate Grants Program.

\section{REFERENCES}

ADAM, P., 1990: SALTMARSH ECOLOGY. Cambridge University Press, Cambridge: $461 \mathrm{pp}$.

BOUSFIELD, E.L., 1973: SHALLOW-WATER GAMMARIDEAN AMPHIPODA OF NEW ENGLAND. Cornell University Press, Ithaca, N.Y: 312 pp.

BousfielD, E.L., 1982: The amphipod superfamily Talitroidea in the Northeastern Pacific region. 1. Family Talitridae: systematics and distributional ecology. Publ. Biol. Oceanogr. Natl Mus. Nat. Sci., Ottawa 11: 1-73.

BousfielD, E.L., 1984: Recent advances in the systematics and biogeography of landhoppers (Amphipoda: Talitridae) of the Indo-Pacific region. In Radovsky, F.J., Raven, P.H. \& Sohmer, S.H. (Eds): BIOGEOGRAPHY OF THE TROPICAL PACIFIC. Association of Systematic Collections \& the Bernice P. Bishop Museum, Honolulu.

Campbell, B.M. \& Griffin, D.J.G., 1966: The Australian Sesarminae (Crustacea: Brachyura): Genera Helice, Helograpsus Nov., Cyclograpsus, and Paragrapsus. Mem. Qld Mus. 14: 127-174.
Culmo, F.M., 1982: The systematic staus of Auricula (Alexia) meridionalis Brazier, 1877 and Rangitotoa insularis Powell, 1933 (Mollusca: Pulmonata: Ellobiidae) in Australasia. Rec. Natl Mus. NZ 2(6): 43-48.

DAibER, F.C., 1977: Salt-marsh animals: Distributions related to tidal flooding, salinity and vegetation. In Chapman, V.J. (Ed.): ECOSYSTEMS OF THE WORLD: 1 WET COASTAL ECOSYSTEMS. Elsevier Scientific Publications.

DalBER, F.C., 1982: ANIMALS OF THE TIDAL MARSH. Van Nostrand and Reinhold Co., USA: 422 pp.

DEXTER, R.W., 1947: The marine communities of a tidal inlet at Cape Ann, Massachusetts: a study in bio-ecology. Ecol. Monogr. 17: 261-294.

DUNCAN, K.W., 1994: TERRESTRIAL TALITRIDAE (CRUSTACEA: AMPHIPODA). Manaaki Whenua Press, Lincoln, NZ: $128 \mathrm{pp}$.

Friend, J.A., 1987: The terrestrial amphipods (Amphipoda: Talitridae) of Tasmania: systematics and zoogeography. Rec. Aust. Mus. Suppl. 7: 1-85.

Green, A.J.A., 1961: A study of Tasmanian Oniscoidea (Crustacea: Isopoda). Aust. J. Zool. 9: 258-365.

Green, A.J.A., 1974: Oniscoidea (Terrestrial Isopoda). In Williams, W.D. (Ed.): BIOGEOGRAPHY AND ECOLOGY IN TASMANIA. Dr W. Junk, The Hague.

Griffin, D.J.G., 1971: Distribution of shore crabs in Tasmania. J. Anim. Ecol. 40: 597-622.

Healey, B., 1975: Fauna of the salt marsh, North Bull Island, Dublin (Eire). Proc. R. Ir. Acad. Sect. B 75: 225-234.

Hopkin, S.P., 1991: A key to the woodlice of Britain and Ireland. Field Stud. 7: 599-650.

Hurley, D.E., 1957: Terrestrial and littoral amphipods of the genus Orchestia, Family Talitridae. Trans. R. Soc. NZ 85 : 149-199.

Kirkpatrick, J.B. \& Glasby, J., 1981: Saltmarshes in Tasmania. Occ. Pap. Dep. Geogr., Univ. Tasm. 8: 1-62.

LITTLE, C., 1990: THE TERRESTRIAL INVASION: AN ECOPHYSIOLOGICAL APPROACH TO THE ORIGINS OF LAND ANIMALS. Cambridge University Press, Cambridge: 304 pp.

LUCAS, J.S., 1980: Spider crabs of the family Hymenosomatidae (Crustacea: Brachyura) with particular reference to Australian species: systematics and biology. Rec. Aust. Mus. 33: 148-247.

MacDonald, K.B., 1969: Quantitative studies of salt marsh faunas from the North American Pacific coast. Ecol. Monogr. 39: 33-60.

MaCnaE, W., 1957: The ecology of the plants and animals in the intertidal regions of the Zwartkops estuary near Port Elizabeth, Sourh Africa. Part I. J. Ecol. 45: 113-131.

MaCpherson, J.H. \& GABriel, C.J., 1962: MARINE MOLLUSCS OF VICTORIA. National Museum Victoria, Melbourne University Press, Melbourne: $475 \mathrm{pp}$.

MARSH, J.A., 1982: Aspects of the ecology of three saltmarshes of the Derwent region, and an investigation into the role of the burrowing crab Helograpsus haswellianus (Whitelegge, 1889). Unpubl. Hons thesis, Dep. Zool., Univ. Tasm.: $141 \mathrm{PP}$.

MulCahy, M.E., 1990: Saltmarshes: a route to colonization of land for amphipod Crustacea? Unpubl. Hons thesis, Dep. Zool., Univ. Tasm.: 97 pp.

NicHOL, E.A., 1936: The ecology of a salt marsh. J. Mar. Biol. Assoc. UK 20: 203-261.

ODum, W.E., 1988; Comparative ecology of tidal freshwater and salt marshes. Ann. Rev. Ecol. Syst. 19: 147-176.

PARTRIDGE, T.R. \& WIILON, T.B., 1989: Methods for investigating vegetation/environment relations - a test using the salt marsh vegetation of Otago, New Zealand. NZJ. Bot. 27: $35-47$.

PatTon, R.T., 1942: Ecological studies in a Victorian saltmarsh, Part IV. Proc. R. Soc. Vict. 54: 131

PAviour-SMITH, K., 1956: The biotic community of a salt meadow in New Zealand. Trans. R. Soc. NZ 83: 525-554. 
RANWELL, D.S., 1972: ECOLOGY OF SALT MARSHES AND SAND DUNES. Chapman and Hall, London: $258 \mathrm{pp}$

Richardson, A.M.M., 1993: Tasmanian intercidal Talitridae (Crustacea: Amphipoda). Palustral talitrids: two new species of Eorchestia Bousfield 1984. J. Nat. Hist. 27: $267-284$.

Richardson, A.M.M., 1996: A new species of Protorchestia (Amphipoda: Talitridae) from Marsuyker Island, Tasmania, with a key to the genus. J. Crustacean Biol. 16: $574-583$.

Richardson, A.M.M. \& MulCahy, M.E., 1996: The distribution of talitrid amphipods (Crustacea) on a saltmarsh in southern Tasmania, in relation to vegetation and substrate. Estuarine, Coastal Shelf Sci. 43: 801-817.

Richardion, A.M.M., Monamy, V. \& Serov, P., 1990: A faunal survey of the Minna Creek area [Tioxide (Aus.) Pty. Ltd.]. Report to Environmental \& Technical Services P/L, Hobart: $11 \mathrm{pp}$.

Richardson, A.M.M., Swain, R., \& Smith, S.J., 1991: Local distributions of sandhoppers and landhoppers (Crustacea: Amphipopda: Talitridae) in the coastal zone of western Tasmania. Hydrobiologia 223: 127-140.

Richardson, A.M.M., SWaIN, R. \& Wong, V., in press: Translittoral species and the need to reserve transitional habitats: examples from Tasmanian saltmarshes and other coastal sites. Mem. Mus. Vict.

SMITH, B.J., 1992: Non-marine Mollusca. In Houston, W.W.K. (Ed.): ZOOLOGICAL CATALOGUE OF AUSTRALIA, Vol. 8. Australian Government Publishing Service.

SMITH, B.J. \& KERSHAw, R.C. 1981: TASMANIAN LAND AND FRESHWATER MOLLUSCS. University of Tasmania, Hobart. $48 \mathrm{pp}$.

Subrahmanyan, C.B., Kruczynski, J. \& Drake, S.H., 1976 Studies on the animal communities in two north Florida salt marshes, II Macroinverrebrate communities. Bull. Mar. Sci. 26: 172-195.

SutTon, S.L. \& Harding, P.T., 1989: Interpretation of the distribution of terrestrial isopods in the British Isles. Monit. Zool. Ital. N.S. Monogr. 4: 43-61.

TEAL, J.M., 1962: Energy flow in the saltmarsh ecosystem of Georgia. Ecology 43: 614-624.

WeSTCOTT, G., 1976: Intertidal crabs of Victoria. Vict. Nat. 93: 237-243.

WAISEL, Y., 1972: THE BIOLOGY OF HALOPHYTES. Academic Press, New York: 395 pp.

(accepted 4 February 1997) 